\title{
The Lives and Deaths of an Ethnographic Museum: History, Violence and Curatorial Collaborations in Guinea-Bissau
}

\author{
Ramon Sarró, Ana Temudo
}

\begin{abstract}
This article discusses the history of the National Ethnographic Museum of Guinea-Bissau (West Africa), which was created in 1988, but ceased to exist because of the civil war in 1998-99. It also tells the history of a 2017 exhibition about the museum that we curated around a collection of contact prints kept in the National Directorate of Culture of Bissau that we were able to digitally reconstruct, which serendipitously led to the museum's rebirth. Methodologically, the article illustrates the potential of photography in museum historiography and revitalization. Thematically, it exemplifies the history of museography in West Africa from the mid-1980s through the 1990s, the role of museums in the creation of national heritage, and, by looking at the present situation of the museum at stake, the fragile place that ethnographic museums have in the politics of culture in today's Africa.
\end{abstract}

Key words: Ethnographic Museums; History; Guinea-Bissau; Heritage; Photography.

\section{Introduction}

This article narrates a double story, about which we recently curated a photographic exhibition Blow-Up in Bissau Photography and Museum Revival at the Pitt Rivers Ethnographic Museum, ${ }^{1}$ very briefly described in Sarró and Temudo (2020). On the one hand, we discuss the recovery, through memories, ethnography, and some archival research, ${ }^{2}$ of the history of the National Ethnographic Museum of Guinea-Bissau, which had been closed to the public for several years before we started our research in 2012. On the other hand, we discuss the process of recovery and the revival of the museum to which our collaboration led. This was a serendipitous 'impact' of the research process, but one that we welcomed and embraced. ${ }^{3}$

Our research on the history of the museum started in 2012, when we learned about a collection of contact prints of old photographs that had survived the violent 1998-99 civil war in Guinea-Bissau. The prints, and the material practices of digitizing, printing and carrying them in a suitcase from Bissau to Lisbon and back, of discussing them individually and collectively, etc., became the means by which to recover memories. Through the materiality of the images, people also revived affects, emotions and sentiments of belonging to a project that had started in the mid-1980s. Using the Platonic distinction between mimesis (imitation) and methexis (participation) recently invoked in modern visual theory by philosopher $\mathrm{J}$-L. Nancy (Nancy 2016), we could argue that photographs both connect with the past through mimesis, by faithfully copying the image, and through methexis, by making the observer participate, ontologically speaking, with an entangled history and a lost epoch. Images become in themselves objects of attachment, materially connecting people with a past that took place but is no longer tangible. They are, like the archives that Lévi-Strauss describes in some passages of La Pensée Sauvage, material connectors between the synchronic structures of the present and the diachronic past of our communities (Lévi-Strauss 1962). As objects imbued with their own life, photos become mementoes of personal and collective identity, 'transitional objects' in Winnicott's (1964) and David Parkin's (1999) sense, and particularly important in traumatic and post-traumatic situations. This is what we realized as we started to show the images to our interlocutors and interviewees. An entire world, long 
gone, materialized around us: not only in our shared imaginations but also quite literally, as the museum started to recreate itself as we researched its history.

\section{Photography and Orality: From Flash Bulb Memories to Narrating the Past}

Scholars of memory have made a distinction between episodic memory and narrative memory. Episodic memory is the memory of a moment inscribed in people's cognition with force because a strong emotion accompanies it. It is typical of episodic memory for the individual to remember the event and its context very clearly. For instance, many will remember very well where they were and what they were doing, perhaps even how they were feeling, when they first heard the news of the terrorist attack on New York's Twin Towers on 11 September 2001. Those who were in the city will remember it so vividly that they would probably rather forget. Trauma is linked to episodic memory: the greater the trauma, the more difficult it is to forget. Narrative or semantic memory is the memory of a long-term series of events. It is an exercise in putting episodes into a temporal framework, of constructing a narrative full of semantic content and symbolism in which the emotions of what is remembered do not play a part. For instance, someone telling the story of Jesus will transmit content and perhaps arouse emotions in their audience, depending on the performance and context of the recitation (a gospel passage read in church by a pastor is not the same as that read in a lecture on the history of religion by a professor), but she or he will not be counting on episodic memories to make their message understood by their public. ${ }^{4}$

In our work, episodic memory was important because we had to ask questions about a civil war that destroyed many lives, as well as a museum and other sites of collective memory. Because we realized the painful memories some questions would revive, we decided not to focus on the effects of the war, which marked a watershed in the history of contemporary Guinea-Bissau. We were much more interested in the making of the museum in the 1980 s than in its destruction in 1998. Photographs became the via regia for us to start the investigation. We realized that the metaphor of 'flash bulb memory', often used by cognitive theorists to refer to episodic memory, works in both directions. The episodic memory not only freezes time in a mental image in which the context is fully remembered (like a photograph, hence the name), but also does the opposite: by showing a photograph to someone who had invested a lot of emotion, energy and hope into what they were doing at the time the picture was taken, they reconstruct and remember a much wider context and recall additional, ancillary memories.

Thus, our process in exploring the museum's history was probably different to what might be expected, in that we did not use interviews to complement research previously done in archives but started instead with oral history, albeit a history grounded in the materiality of the contact prints. Combining the ideas of photo-elicitation as a source in the writing of history (Morphy 1989; Tucker 2009) and photographs as social salient objects (Edwards 2002: 67), the contact prints became for us both a method for recovering memories and a collection of fragile materialities in their own right. Given that most of the objects portrayed in the images no longer existed (and the images themselves only existed in the volatile form of contact prints), we could not do anything other than talk with people about the history of the museum. Archives about it are virtually non-existent, most documents having also been lost in the 1998-99 civil war. ${ }^{5}$ All the people involved in our research, all from different fields of work and geographies, testified to specific moments in the museum's life and thus helped us extract narratives, chronologies and broader contexts out of the tiny images we showed them.

In the remainder of the article, we will relate the history of the museum as far as we have been able to reconstruct it with the help of our interlocutors and the available documents. Then we will focus on the exhibition we curated in 2017 and how this collaboration led to the reopening of the museum. We finish the article with a discussion of the museum's final closure in 2020, asking ourselves, and our readers, what place ethnographic museums have in the postcolonial and decolonial world of today.

\section{The Early Days of the Museum}

The National Ethnographic Museum of Guinea-Bissau was officially inaugurated on 31 May 1988 , but field collection and cataloguing activities began some years earlier. As stated in 
internal documentation from 1985 found in the museum's archive, the project to create a museum under the supervision of the National Directorate of Culture arose from the need 'to study, collect, conserve and disseminate Guinean culture and preserve Guinean heritage'. Guinea-Bissau was then a very young country, having only declared independence from Portugal in 1973, after a long decade of very violent liberation struggle. The first years of the country proved quite turbulent. A bloodless coup d'état in November 1980 put Bernardo 'Nino' Vieira in power, and he very quicky started a programme of nation building, in an attempt to bring together the citizens of the country despite their ethnic, linguistic, religious and political differences. In a visit to Portugal in the mid-1980s, one of the members of Vieira's government publicly lamented that Guineans had to travel to Lisbon to see their heritage (Anonymous 1985: 13). His words came at a time when conversations were probably starting to take place about having a museum in Guinea-Bissau.

The then Secretary of State for Culture and Sports, Alexandre Furtado, initiated and gave shape to all the activities that led to the creation of the museum, including the establishment of institutional partnerships. The 'Commission for the Installation of the National Museum' project then ran for three years before the museum's public opening.

Between 1987 and 1995, the museum benefited from international support from institutions such as the Swedish International Development Cooperation Agency and the WAMP or West African Museum Project (later West African Museum Programme). Through the latter, sponsorship was obtained from the Ford Foundation and the Rockefeller Foundation for travelling exhibitions both within the country and abroad. Some Portuguese institutions collaborated in the training of museum technicians. Under the leadership of Mário Moutinho, a delegation from the International Movement for New Museology (MINOM) - one of the bodies that defined the guidelines for eco-museums and community museums together with the International Council of Museums (ICOM) - travelled several times to Bissau to help train technical staff and hold seminars on museology.

Guinea-Bissau's National Ethnographic Museum offers a very good example with which to theorize about the fate of ethnography in postcolonial Africa. However, despite the museum's official birth in the post-colony, we must dig into colonial times if we are to reconstruct its history. In Portuguese colonial Bissau there was already a rich 'Ethnographic Section' in the Museum of Portuguese Guinea (Lampreia 1962), a museum created in 1947 and located from the early 1950s in a very big, modernist building in what was then called Empire Square (today's National Heroes Square). To date, the connection and continuities between the colonial and the postcolonial ethnographic collections have not been studied. The building where the colonial museum was housed became, after independence, the Ministry of Foreign Affairs. The valuable ethnographic objects housed there were scattered, becoming 'diasporic objects', to use the apt concept of Peffer (2005) and Basu (2011), and it is difficult today to reconstruct their itineraries. Some of them undoubtedly left the new country and migrated, like the colonizers, to Portugal; others remained in private hands in independent Guinea-Bissau. But we do know that many of the objects that were collected in the mid-1980s to create the National Ethnographic Museum had been part of the colonial Museum of Portuguese Guinea and had been kept in waiting in one house or another between 1974 and 1987. These objects embodied the transition from colonial museum to postcolonial national museum, as well as all the ambivalences involved in the making of something as loaded with coloniality as an 'ethnographic museum' in the post-colony.

Of particular importance in the making of the museum was the collaboration with the British Museum in the UK. In the late 1980s, Malcolm McLeod, Ethnographic Keeper of the British Museum's African collection, visited Guinea-Bissau on behalf of the British Museum's 'African Museums programme'. His visits there coincided on several occasions with those of his colleague Philip Ravenhill, who travelled to Guinea-Bissau in 1987 and 1988 as part of the support activities of WAMP, the international programme he had created and then directed. In 1989 McLeod spent almost half a year in the country working with the museum director Leonardo Cardoso and his team on the newly opened museum. Together, they collected many objects for the museum in Bissau as well as for the British Museum and built two fabulous photographic collections. In an interview in 2019 McLeod told us that, following the British Museum's code of practice, every time they wanted to collect an object, they would make sure the villagers were happy to offer two specimens. McLeod would then 
let Cardoso choose which of the two would be for the museum in Bissau. This code applied to everyday objects (relating to hunting, cooking and farming, and other tools used daily) but not to ritual masks or sculptures considered sacred by the community, which were not taken away in those missions. ${ }^{6}$

The National Ethnographic Museum of Guinea-Bissau was opened on 31 May 1988 in the Ajuda neighbourhood of Bissau. International institutions such as the MINOM and the ICOM were very actively engaged in supporting the institution (e.g., Cardoso 1994). Portuguese museum scholar António Nabais went to Guinea-Bissau on several occasions to offer training in museology, as did many other Portuguese scholars; while some young Bissau-Guinean technicians were sent to Portugal to undergo training in museum studies and practices.

In 1989, Portuguese architect Alexandre Alves Costa was invited to Guinea-Bissau to design the building for a national museum, which would incorporate the National Ethnographic Museum but also many other aspects of Guinean culture (history, theatre, music, dance, art). Although this never took off, it illustrates the tension that existed in those years between the ideas of a national ethnographic museum and a national museum. The documentation we found from the 1980 s is particularly ambivalent, sometimes contradictory. It looks as though some people were actively engaged in the creation of a national ethnographic museum, while others were rather convinced that they were building a national museum.

Individual memories do not help reconstruct the debates. Malcolm McLeod told us that the museum was thought of as an ethnographic museum from the outset, and in fact he had kept some documentation that testified to this effect. Similarly, the museum's first director, Cardoso, had no doubt he was directing a national ethnographic museum. In an interview with Tavares Pinto, he said that the concept of an 'historical ethnographic museum' was the most appropriate in capturing his philosophy and approach (Tavares Pinto 1994).

Yet, António Nabais told us exactly the opposite: the museum was not an ethnographic museum. In 1989, Nabais was invited to Bissau to offer training to the technician of the new museum. He told us they invited him because Guinea-Bissau was constructing a national museum. In Nabais's view, it would not have made much sense to construct an ethnographic museum in Bissau. ${ }^{7}$

While difficult to resolve with such contested memories and documents, the conceptual tension between different denominations is revealing. On the one hand, it testifies to the need to create a national museum felt by many people in the 1980s and early 1990s, a need very much in line with Vieira's nation-making efforts. On the other hand, it testifies to the ambivalences of 'ethnography' in the post-colony, an aspect to which we will return later. In any case, it would be difficult to say that the museum as it opened in 1988 was strictly ethnographic. It also contained portraits of the Portuguese governors of Bissau and other clearly historical items, such a very rich collection of tapes, now lost forever, where oral history recorded in the field was kept.

The museum operated for just ten years. In 1998, as already stated, a civil war ravaged the country's capital for an entire year. The building that housed the museum was used as a barracks for Senegalese troops who came to support the government of President Bernardo Vieira, which was under threat from the so-called rebel forces led by General Ansumane Mané. As a result, the ethnographic collection and documentation suffered irreparable damage. During the war, many objects and documents were destroyed. These included audio files recorded in the field, an extraordinary collection of textiles, for which the museum was particularly well known, and a valuable photographic archive.

Photography was very important in the exhibition philosophy of the museum. Marked by a strong didactic character and a connection with the community (very much in line with the community-oriented museum philosophy of the 1980s), the museum displayed photographic records in dialogue with the objects collected in the field in order to bring the observer closer to the places and daily activities of the Bissau-Guinean population. Unfortunately, this visual material, as well as a great many objects, display cases and documents disappeared during the war, and the terrible conservation conditions to which the objects were subjected when the museum was lost accelerated the deterioration of many of them.

Two years after the end of the civil war, in 2001, the museum team succeeded in reopening the museum. This project lasted until 2009 - another very violent year in the history 
of the country - when Bernardo Vieira, who was again president of the country, was brutally assassinated along with the Chief of the Army. Once again the victim of political instability, the museum was closed for good. The building in Ajuda neighbourhood was destined for other uses, although it has remained empty and closed ever since. The museum objects that survived the war, some of which had been held in waiting in the transition from the colonial museum to the new museum between 1974 and 1987, were sent into limbo again.

On closing it in 2009, the government announced that the museum would reopen later in the building that housed the National Directorate of Culture. The remaining objects were transferred to that historic building, which had housed no less than the Museum of Portuguese Guinea during the colonial period colony and the Ministry of Foreign Affairs in the early days of the new nation-state and has always been an object of desire for many actors in the Bissau-Guinean political arena. In 2013-17, when we conducted much of the fieldwork leading to the 2017 anniversary exhibition (see below), we could sense the tension. 'We are in a constant fight', the Director of Culture told us in 2014. 'This building belongs to us [the National Directorate of Culture], but some people say it should be destined to other ministries; but they are not going to win.'

\section{Our Collaboration with the Museum}

In December 2012, one of the authors of this article (Sarró) visited an exhibition at the FrancoGuinean Cultural Centre in Bissau, where some ethnographic pieces from Guinea-Bissau were on display. It was stated that they had been borrowed from the National Ethnographic Museum. Curious about the existence of such a museum, he conducted a quick search on the Internet and found a defunct website for the Ministry of Culture that referred to the museum and, tantalizingly, to the existence of a photographic collection in it. ${ }^{8}$ Sarró contacted the director, the late Eveline Marta Diallo, as well as the deputy director of the National Ethnographic Museum of Guinea-Bissau, Albano Mendes. The museum was not open to the public at that time, and the objects were being kept at the National Directorate of Culture. The director and deputy director of the museum each had a huge office in the Directorate of Culture building, in which they kept the objects that made up the entire ethnographic collection.

Albano Mendes showed Sarró the images referred to on the Internet. They were not photographs but 35 sheets of contact prints, with about 30 images per sheet. The printed photos and their negatives had disappeared during the conflict, but Albano Mendes had carefully stored and looked after the contact prints since 1999. Although in poor condition, the evidence was of great value, as it testified to forgotten episodes and told a little-known story. Indeed, between 1986 and 1998 the museum, which came to have its own photographic laboratory, kept systematic visual records of its collection and its activities. Unfortunately, the remaining images only told the story between 1986 and 1990.

In March 2016, thanks to support from the University of Oxford, Albano Mendes (by then promoted to director of the museum) was able to travel to Lisbon for a month to work with Ramon Sarró and the artist, museum studies researcher and curator, Ana Temudo to scan the images with the resolution needed to print, exhibit and publish them. Between 2013 and 2017 , we conducted many interviews with the main promoters of the creation of the museum in Bissau, and many other Guinean scholars and artists. António Nabais not only offered up many memories of his collaboration with the museum in Bissau in the early 1990s but also gave us valuable documentation from his personal archives.

The scanned images show the museum's early work from 1986 to 1990, from field collection to research and the creation of the 'Installation Commission'. Taken together, they constitute a record of enormous historical value that documents the ethnographic expeditions into different parts of the interior of Guinea-Bissau in search of objects and historical memories, as the team of the Installation Commission recorded hours of conversations with elderly people in the villages (as stated above the many tapes they collected were also lost in the civil war of 1998-99). The images also testify to the valuable collection of ethnographic objects that could be seen in Bissau before they were lost. The material culture of Guinea-Bissau, a country that boasts a unique ethnic diversity, offers a very rich stylistic variety, which the authors of the photographs fully documented. 
The exhibition The National Ethnographic Museum: 30 Years of History opened at the National Directorate of Culture's building on 15 September 2017. The main objective was to present the material culture of Guinea-Bissau, to explain the history of the museum, and to invite reflection on the consequences of a war that caused not only many human losses, but also the dismemberment of a very important museum collection.

Prior to the opening of the exhibition in September 2017 there was nothing to suggest that the façade of the National Directorate of Culture's building on National Heroes Square concealed an ethnographic collection. Up until then, the collection could only be visited by appointment with the National Director of Culture, the director of the National Ethnographic Museum, or her deputy director.

In early September 2017, we began working with the staff of the museum to restore several rooms in the building of the National Directorate of Culture and undertake a catalogue of all the objects in storage. Curator Ana Temudo selected the objects that best related to the images printed on the roll-up banners, in order to trigger a dialogue between the images and the material culture. The focus of the exhibition remained on the contact prints, which were displayed on a big table placed in the centre of the main room. By looking at the roll-up banners and the prints, the public could easily realize that the images on the banners had been enlarged from those tiny contact prints.

In enlarging and organizing the images, we tried to reconstruct the visual epistemology of the museum in the 1980s and 1990s. In that decade, the museum was committed to materially and graphically showing the dynamics of the activities that made up the economic, social and cultural life of the inhabitants of Guinea-Bissau. The images showed the arts of basket weaving, blacksmithing, weaving and pottery, rituals and ceremonies, games and commemorations, places of habitation, housing and coexistence, places of worship and places of historical memory, as well as the first records of the museum and its outreach activities.

The opening of The National Ethnographic Museum: 30 Years of History exhibition on 15 September 2017 was accompanied by a colloquium to which we invited some of the members of the 'Installation Commission' of the 1980s. They recalled the experience of setting up the museum in the late 1980s and discussed the possible future of the museum and the cultural sector in the country. It was also an opportunity for some young people (mostly cultural activists and artists) to express their discontent over the fact that their rulers were persisting with an ethnographic museum when, they felt, a history museum or a cultural centre would be more appropriate. ${ }^{9}$

Little did we expect, when we organized the exhibition in 2017, that it would become the actual reopening of the museum. Our intention was to tell the story, to remember that a museum had been inaugurated 30 years earlier and that it had worked in Bissau for many years. We planned for the exhibition to last for some months. However, the very day the exhibition opened, journalists from the national and international media began speaking of the reopening of the National Ethnographic Museum of Guinea-Bissau. When we asked the National Director of Culture how long he would keep the exhibition open to the public, he told us he had no intention of closing it. In fact, at the very opening of the exhibition, the Minister of Culture publicly said he would donate 1,000,000 CFA Francs (around 1,200 USD) to the museum so that it could purchase new objects and improve the display infrastructure. It was clear that, in doing this, the Minister and the Director of Culture were making it visible that the building belonged to them. A few months later, the museum started to gain momentum. Because of two big banners we had had printed and hung on the exterior walls, various publics in Bissau began to pay attention. More and more tourists started to visit, and thanks to the engagement of its director, who was often interviewed in national media, more and more schools, universities and other centres in Bissau began using the museum as part of their external activities.

The museum's director, Albano Mendes proved an erudite guide, who knew every object, as well as every photograph, and how to explain its history and cultural meanings. Little by little he dismantled the 30 Years of History exhibition and started to reorganize the museum's display according to his own vision. Some people donated objects and images. When we visited the museum again at the end of 2018, it had a totally different layout, with many more objects and new collections of images. The visitors' book was full of commentaries praising the collection as well as the work of Albano Mendes and his staff. 
Based on the experience of organizing the 2017 exhibition, the three of us co-authored a visual essay (Mendes et al. 2018) which contained many of the photos we had scanned, as well as images of the exhibition itself. In January 2019, the book was launched in the museum itself, and the event, chaired by the new Minister of Culture, gave rise to a second lively debate about the role of that museum and of museums more generally in GuineaBissau. We became a bit apprehensive about the number of people expressing criticism of the fact that we had revitalized an ethnographic rather than a national museum. António Nabais also told us in 2019 that the ethnographic museum we had revitalized in 2017 had very little to do with the original national museum he had helped build in the early 1990s, when he was invited to offer courses on museums in Bissau. Taking these criticisms on board, we told Albano Mendes in Bissau in 2019: 'Perhaps we have made a mistake, perhaps you guys should rename the museum the National Museum?' Yet, he was adamant that this was a misconception. He replied that he had been employed in the museum since 1991, that it had been born an ethnographic museum and that it should be kept as such. Albano Mendes was indeed passionate about ethnography and had a very 'daily life' approach. In his view the museum should document the arts of subsistence, the technologies of livelihoods of the everyday man and woman in the hinterland of Bissau, allow for comparisons, etc. While other people felt an ethnographic museum in Bissau was unnecessary (and perhaps too reminiscent of colonialist epistemologies), Albano Mendes felt it was entirely necessary.

\section{The End of a Museum}

In 2019 political changes took place in Guinea-Bissau again. As a consequence, the Ministry of Culture, with which we had collaborated since 2012, was disbanded. The new government created instead a State Secretariat of Culture that housed two national directorates: the National Directorate of Culture and the National Directorate of Heritage. We heard that a 'network of museums' would be created and that the National Ethnographic Museum of Bissau would be the administrative centre of the network. By early 2020, Sarró had secured funding from Oxford to fly again to Bissau and work with Albano Mendes to gather information about the life of the museum and discuss the new administrative landscape with him. Covid-19 thwarted that plan, and of course affected life and politics in Bissau greatly. Driven by tensions that remain unclear to us, the building changed tenant again, and the National Directorate of Culture moved out. In September 2020, we were informed that the museum, which had had no visitors since the outbreak of the pandemic in February 2020, had been officially closed, and that the objects were to be removed from the historic building (which belongs now to the Presidency). It was a sad moment again, particularly for Albano Mendes who had put so much energy in keeping the museum afloat and was now told he risked of being made redundant. Yet, there seems to be a silver lining for him, since, as of August 2021, he is still employed by the National Directorate of Culture and is also collaborating with the INEP (Guinea-Bissau's National Research Institute) on developing a 'museum of empire' - not the Portuguese empire, but the Mande empire - to be built in the historic site of Kansala, a place of utmost outmost importance in the history of the Mande empire. It is too early to assess what impact this project will have, but it is in itself quite telling that the closing of an ethnographic museum, with all its historical ambivalences, legacies and partnerships with Northern institutions, is being directly followed by conversations about the creation of such a non-ambivalently 'Global South' initiative as a museum of the Mande civilization, which spanned many West African nation-states.

The idea of the current government, as transmitted by the Secretary of State of Culture to us, is to temporarily close the National Ethnographic Museum in order to create a 'Palácio Nacional da Cultura' (National Palace of Culture) that will incorporate the museum and all the other activities under their aegis (the National Institute of Cinema, the National Ballets, etc). In this it will follow a plan reminiscent of that already proposed in 1989, when architect Alves Costa was invited to the country to design a huge meta-museum that never took off. It will be interesting to see whether, whenever the museum reopens in the Palácio Nacional da Cultura, it reopens as a national ethnographic museum or as a national museum. As we have seen, debates still divide opinions in Bissau and abroad. In the meantime, the objects are held, in limbo again, in a room lent by the National Institute of Cinema. Some of the 
objects, like one Nalu drum, have been kept in waiting many times, housed in the Museum of Portuguese Guinea in colonial times and housed in the National Ethnographic Museum since its opening in 1988, changing buildings every decade or so. They embody the resilience of Bissau-Guinean culture underneath the very violent political transitions the country has suffered since the 1960s.

\section{Discussion}

Influential anthropologist and essayist Francis Nyamnjoh has recently highlighted the usefulness of such concepts as 'frontiers', 'incompleteness' and 'conviviality' in understanding the conditions of possibility of postcolonial life in Africa today (Nyamnjoh 2017). These notions seem to apply particularly well to Guinea-Bissau, a country that is in itself a clash of Western and internal frontiers (as embodied in its main language, Kriol, and its rich material and religious diversity), and a place so 'incomplete' that many scholars have not hesitated to call it a 'failed state' (Green and Chabal 2016), in which 'conviviality' (convivência) is a concept that governs relations and inter-ethnic ethics (Sarró and de Barros 2016). Nyamnjoh was not thinking about Bissau or about museums when he wrote his seminal article on conviviality, but the fluidity of agency in an increasingly incomplete world that he was trying to capture applies very well to our story of a very fluid and far from over history.

That individual objects have a biography of their own, being able to die and be reborn, is now commonly understood in material culture studies (e.g. Kopytoff 1988), and was already established in the 1953 film about African art Les statues meurent aussi (Statues Also Die, Alain Resnais). In our research on the trajectory of the National Ethnographic Museum of Bissau and its colonial 'proto-history', and building on previous authors (e.g., Segalen 2005), we have reached the conclusion that, rather than the individual fate of objects, we should pay more attention to the life and death of museums, as total institutions assembling a whole set of objects and relations (with history, with communities, with international agencies). The National Ethnographic Museum of Bissau did not only have one life and death, but many. It died in 1974 with the colony. Reborn in 1988, it died again in 1998 with the civil war. Reopened in 2001, it died again in the violent year of 2009 with the final closure of the post-war reconstruction. Reopened in the building of the Directorate of Culture in 2017, it died yet again in 2020, when the newly elected government decided the Presidency should take control of the building.

Our engagement with the museum illustrated several problems that are often discussed in the literature around museums in postcolonial Africa:

First, the fragile place of ethnography in the post-colony and the problematic continuity between colonial understandings of this discipline and postcolonial display practices. While it has been argued that ethnographic museums can be channels of ancestral pride (Adande 1995), there have been many authors, starting with Angolan Henrique Abranches (1989), who have reminded scholars of the dependency of ethnography museums on conceptual and institutional structures inherited from the colonial past.

Should ethnographic museums still exist? Or should they be replaced by more imaginative ways of displaying the works of culture and the preoccupations of individuals in a society? Twenty years ago, Ardouin was already criticizing most museums in West Africa for reproducing 'an ethnographic, a-historic, if not downright folkloric image of the societies they represent' (Ardouin 2000: 1), and similar views have been voiced by many other authors (Arinze 1998; Adedze 2002; Edwards et al. 2006). Yet, Kratz (2014) has encouraged scholars to study the entanglements of ethnography with history, particularly in contexts, such as in most African countries, where there are no art museums and where the witnessing aspect of ethnography to elucidate historical changes becomes particularly useful. ${ }^{10}$

Second, the delicate balance between a national culture and ethno-linguistic particularities and the role of museums in navigating them, especially in post-conflict situations. Should a museum in a capital such as Bissau display the overall culture of the nation state, or that of the ethnic groups in its territory? While ethnography can be criticized for being a colonizing practice, official national narratives, as pointed out by scholars such as Basu (2008) and Makuvasa, ${ }^{11}$ can also be blamed for exercising an 'internal colonialism' that homogenizes the perception of a single society, promoting heritage technologies that 
privilege certain official memories while repressing others (de Jong and Rowlands 2007; for earlier formulations of this problem, see Myles 1976 and Abungu 2005). A parallel problem is that museums in West Africa risk enlarging the divide between the urban capital and the rural domain, where most farmers, traders and other citizens live (Kusimba and Klehm 2013). This becomes, then, an ethical problem. To whose benefit can one ignore, in the name of the nation state, the livelihoods and everyday realities of the peasants? This debate is particularly important in the case of Guinea-Bissau because of the 1998-99 civil war which, it has been argued (Temudo 2008) thas hardened the division between the creolized communities of the Atlantic capital and the 'deep rural' realities of the hinterland.

Third, the struggle for reconciliation in a society after an armed conflict and its possible connections with heritage and museums. What are the relations between healing a nation and curating its heritage, or between 'curating' and 'repairing', as Michael Rowlands (2008a) so astutely asked? Heritage may play a role in reducing ethnic divisions (Kusimba and Klehm 2013) but, as several authors have shown, it can also reify official narratives over alternative ones, as has been argued for South Africa (Meskell and Scheermeyer 2008), or it can raise bitter debates as to whether conflicts should be remembered or forgotten, as Michael Rowlands has documented for post-war Liberia (Rowlands 2008b). The situation we found in Guinea-Bissau has a parallel with that analysed by Paul Basu (2008) in Sierra Leone. The insistence on the civil conflict, singled out today as an axial moment in a foundational narrative for the nation state, glosses over the fact that the entire Upper Guinea Coast, and certainly the coast of Guinea-Bissau (see e.g. Hawthorne 2003) has been a very violent zone over the last centuries. While the 1998-99 civil conflict has indeed created a watershed in popular memory, official narratives and scholarly analysis (see, e.g., the collection of essays in Chabal and Green 2016), a proper analysis of Guinea-Bissau's cultural heritage should take into account a deeper history of suffering and dispossession, rather than give the false impression that everything was peaceful convivência prior to 1998. Perhaps coming to terms with this violent history is necessary in order for museums to become more meaningful for future generations, as Paul Basu $(2008,2011)$ has suggested, and in order for African nations to 'update culture' as recommended by Alpha Oumar Konare (1995:8) almost three decades ago, an update in which objects become mechanisms for conveying historical and cultural awareness.

Last but not least, our research has unearthed some neglected Global North-Global South partnerships that took place in the 1980s, with programmes such as WAMP and the British Museum, together with partnerships with the UNDP (United Nations Development Program) and the Swedish Development Agency that paradoxically encouraged ethnographic museums in Africa in the very days when major ethnographic museums in Europe were closing. As testified in some writings by Ravenhill, the role of ethnography in the post-colony was perceived as problematic when planning new museums in Africa, for it risked perpetrating what he called 'the colonial ethnic paradigm' of the past. Museums in West Africa, Ravenhill wrote, 'must go beyond folkloric approaches to find the historical significance, the aesthetic creativity, and the present educational worth of their collections' (Ravenhill 1996: 279). The intentions and philosophies of these international collaborations were based on fairness and equity. However, we need to revisit them and question the extent to which, despite their wellmeant intentions, they ended up reproducing an anachronistic notion of ethnography that was problematic in a postcolonial state. What lessons can we learn for future collaborations between North and South museums?

At the practical and methodological level, this article has illustrated the importance of photography as evidence of history and as a tool for retrieving memories and narratives. While the relationship between photography and colonialism has been profusely researched, our study suggests that photographic archives must also be used to study the early years of the post-colony, and thus give historical depth to the decolonizing practices and discourses at the heart of the new epistemologies of African studies.

The history of the National Ethnographic Museum of Guinea-Bissau encapsulates the transition of museums from colony to post-colony, and from post-colony to the de-colonial moment of today, when global histories are being reconsidered, museums in Africa reinvented, and the place of ethnography as a mode of production of knowledge subjected to particularly critical scrutiny. For all we know, the museum may have died forever, but the sculptures, masks 
and daily objects are all there, and it is up to the people of Guinea-Bissau to decide what narratives they want to construct with them. We can only hope that the images and footage we took while collaborating with the museum over the last decade will help future researchers reconstruct the problematic story and place of an ethnographic museum in West Africa.

Received: 25 May, 2021

Finally accepted: 7 September 2021

\section{Notes}

1 The exhibition opened on 15 December 2019. It should have closed on 5 May 2020 but owing to COVID-19 it has remained open in the Museum and, as of August 2021, it can still be visited there. https://www.prm.ox.ac.uk/event/blow-up-in-bissau

2 Archival research on the museum was very limited because, owing to the violence of the civil war, the museum has kept no archives, except for a very limited number of documents we were able to consult in Bissau. We also consulted personal archives of our interviewees, most notably António Nabais, who has a very rich collection of documents about the Portuguese-Bissauan collaborations of the early 1990s, and Malcolm McLeod, who keeps some documents about his missions in Bissau in the late 1980s.

3 The reopening of the museum as a direct result of our collaboration features on the 'Impact' website of the University of Oxford. For more details, see https://www.anthro.ox.ac.uk/ article/blow-up-in-bissau-a-photographic-exhibition-organised-by-dr-ramon-sarro-andcolleagues-has-h. In the rest of this article, we use 'the museum' as shorthand for the National Ethnographic Museum of Guinea-Bissau.

4 We use the gospels as an example because the distinction between episodic and narrative memory is particularly important in religious transmission, as the works of Harvey Whitehouse (2000) have demonstrated.

5 The war put an end to a lot of documentation kept in the museum, but also, very dramatically, to the National Archives stored in the adjacent building.

6 Malcolm McLeod, personal communication, 30 May 2020.

7 António Nabais, personal communication, 26 April 2019.

8 The defunct website explicitly invited external collaborators to help with the collection of images, which needed cataloguing. This invitation was one of the main reasons why Ramon Sarró wanted to meet the director.

9 For more information on the curational experience and on the opening day, see the account, in Portuguese, by the curator (Ana Temudo, A. [2018] 'Padi Sabi: o renascer do museu de Bissau', https://www.buala.org/pt/vou-la-visitar/padi-sabi-o-renascer-do-museu-debissau (accessed 29 August 2021).

10 Corinne A. Kratz (2014) 'Adapting and Transforming Ethnographic Exhibits', https://leadingedge.iac.gatech.edu/aaproceedings/adapting-and-transforming-ethnographic-exhibits/ (accessed 25 August 2021).

11 Simon Makuvaza (2002) ‘Towards a New Type of 'Ethnographic' Museum in Africa', https:// icme.mini.icom.museum/wp-content/uploads/sites/16/2019/01/ICME 2002 makuvaza. pdf (accessed 25 August 2021). 


\section{References}

Abranches, H. (1989) Identidade e Património Nacional, Luanda: União dos Escritores Angolanos.

Abungu, L. (2005) 'Museums and Communities in Africa: Facing the New Challenges', Public Archaeology, 4 (2-3) 151-54.

Adande, A. (1995) 'Plea for a Traditional Arts and Crafts Museum', in Claude Daniel Ardouin and Emmanuel Arinze (eds) Museums and the Community in West Africa, 68-80, Washington: Smithsonian Institution Press for the West African Museums Programme.

Adedze, A. (2002) 'Symbols of Triumph: IFAN and the Colonial Museum Complex in French West Africa (1938-1960)', Museum Anthropology, 25 (2) 50-60.

Anonymous (1985) ‘Em Lisboa: etnologia africana de portas fechadas', Africa Hoje, 1 11-3.

Ardouin, C.D. (2000) 'Introduction', in Claude Daniel Ardouin and Emmanuel Arinze (eds) Museums and History in West Africa, 1-2, Oxford and Washington: James Currey for the West African Museums Programme.

Arinze, E.N. (1998). 'African Museums: The Challenge of Change', Museum International, 50 (1) 31-7.

Basu, P. (2008) 'Confronting the Past?: Negotiating a Heritage in Sierra Leone', Journal of Material Culture, 13 (2) 233-47.

(2011) 'Object Diasporas, Resourcing Communities: Sierra Leonean Collections in the Global Museumscape', Museum Anthropology, 34 (1) 28-42.

Cardoso, L. (1994) 'As colecções do Museu Etnográfico da Guiné-Bissau: Política de aquisição e natureza', IV Encontro de Museus de Países e Comunidades de Língua Portuguesa, 33-4, Macau: ICOM.

Chabal, P. and Green, T. (eds) (2016) Guinea-Bissau: Micro-State to 'Narco-State', London: Hurst and Company.

de Jong, F. and Rowlands, M. (2007) 'Introduction', in Ferdinand de Jong and Michael Rowlands (eds) Reclaiming Heritage: Alternative Imaginaries of Memory in West Africa,13-29, Walnut Creek: Left Coast Press

Edwards, E. (2002) 'Material Beings: Objecthood and Ethnographic Photographs', Visual Studies, 17 (1) 67-75.

Edwards, E., Gosden, C. and Phillips, R.B. (2006) Sensible Objects, London: Routledge.

Green, T. and Chabal, P. (2016) 'Introduction', in Patrick Chabal and Toby Green (eds) Guinea-Bissau: Micro-State to 'Narco-State', 1-16, London: Hurst and Company.

Hawthorne, W. (2003) Planting Rice and Harvesting Slaves: Transformations Along the Guinea-Bissau Coast, 1400-1800, Portsmouth, NH: Heinemann.

Konare, A.O. (1995) 'The Creation and Survival of Local Museums', in Claude Daniel Ardouin and Emmanuel Arinze (eds) Museums and the Community in West Africa, 5-10, Washington: Smithsonian Institution Press for The West African Museums Programme. 
Kopytoff, I. (1988) 'The Cultural Biography of Things: Commoditization as Process', in Arjun Appadurai (ed) The Social Life of Things: Commodities in Cultural Perspective, 64-92, Cambridge: Cambridge University Press.

Kusimba, C. and Klehm, K. (2013) 'Museums and Public Archaeology in Africa', in Peter Mitchel and Paul J. Lane (eds) Oxford Handbook of African Archaeology, 227-37, Oxford: Oxford University Press.

Lampreia, J. (1962) Catálogo-Inventário da Seccão de Etnografia do Museu da GuinéBissau, Lisbon: Junta de Investigações de Ultramar.

Lévi-Strauss, C. (1962) Le Pensée Sauvage, Paris: Plon.

Mendes, A., Sarró, R. and Temudo, A. (2018) O Museu Etnográfico Nacional da Guiné Bissau: Imagens para uma história, Porto: Greca.

Meskell, L. and Scheermeyer, C. (2008) 'Heritage as Therapy: Set Pieces from the New South Africa', Journal of Material Culture, 13 (2) 153-73.

Morphy, H. (1989) 'Eliciting and Recording: Reflections on the Use of Photography in the Field', Journal of Museum Ethnography, 135-56.

Myles, K.A. (1976) 'Museum Development in African Countries', Museum International, 28 (4) 196-202.

Nancy, J-L. (2016) 'The Image: Mimesis and Methexis', in Adrienne Janus and Carrie Giunta (eds) Nancy and Visual Culture, 73-92, Edinburgh: Edinburgh University Press.

Nyamnjoh, F.B. (2017) 'Incompleteness, Frontier Africa, and the Currency of Conviviality', Journal of Asian and African, 52 (3) 253-70.

Parkin, D. (1999) 'Mementoes as Transitional Objects in Human Displacement', Journal of Material Culture, 4 (3) 303-20.

Peffer, J. (2005) 'Africa's Diasporas of Images', Third Text, 19 (4) 339-55.

Ravenhill, P. (1996) 'The Passive Object and the Tribal Paradigm: Colonial Museography in French West Africa', in Mary Jo Arnoldi, Christraud M. Geary and Kris L. Hardin (eds) African Material Culture, 265-82, Bloomington, IN: Indiana University Press.

Rowlands, M. (2008a) 'Aesthetics of Touch among the Elderly', in Helen J. Chatterjee (ed) Touch in Museums: Policy and Practice in Object Handling, 187-97, Oxford and New York: Berg.

(2008b) 'Civilization, Violence and Heritage Healing in Liberia', Journal of Material Culture, 13 (2) 135-53.

Sarró, R. and de Barros, M. (2016) 'History, Mixture, Modernity: Religious Pluralism in Guinea-Bissau Today', in Patrick Chabal and Toby Green (eds) Guinea-Bissau: Micro-State to 'Narco-State', 105-24. London: Hurst and Company.

Sarró, R. and Temudo, A. (2020) 'Blow-Up in Bissau: Photography and Museum Revival in West Africa', Friends of the Pitt Rivers Museum Magazine, 98 8-9.

Segalen, M. (2005) Vie d'un Musée: 1937-2005, Paris: Stock.

Tavares Pinto, D. (1994) 'Dois dedos de conversa com o diretor do Museu Etnográfico da Guiné-Bissau', Tcholona 2-3 43-7. 
Temudo, M.P. (2008) ‘From "People's Struggle" to "This War Today": Entanglement of Peace and Conflict in Guinea-Bissau', Africa: Journal of the International African Institute, 78 (2) 245-63.

Tucker, J. (2009) 'Entwined Practices: Engagements with Photography in Historical Inquiry', History and Theory, 48 (4) 1-8.

Whitehouse, H. (2000) Icons and Arguments, Oxford: Oxford University Press.

Winnicott, D.W. (1964) The Child, the Family and the Outside World, London: Penguin.

\section{Authors}

Ramon Sarró. Associate Professor at the School of Anthropology and Museum Ethnography, University of Oxford. He has conducted fieldwork in Guinea, Guinea-Bissau, Democratic Republic of Congo, and Angola on religion, material culture, iconoclasm and the politics of heritage.

https://www.isca.ox.ac.uk/people/dr-ramon-sarro\#/

Email:ramon.sarro@anthro.ox.ac.uk

Ana Temudo. PhD candidate in Heritage Studies, Universidade Católica Portuguesa, School of Arts, Research Centre for Science and Technology of the Arts. The doctoral project 'Representational Politics of Guinean Heritage in Portuguese Museums in the Transition from Colonial to Postcolonial Period: Histories, Transits and Discourses' is funded by the Foundation for Science and Technology (FCT) and the European Union (EU).

PhD individual scholarship REF 2020.08039.BD.

E-mail: anatglima@gmail.com. 